\section{Characterization of Morphological and Fruit Quality Traits of Coconut (Cocos nucifera L.) Germplasm}

\author{
Ruining Zhang \\ Coconut Research Institute, Chinese Academy of Tropical Agricultural \\ Sciences, Wenchang, Hainan 571339, People's Republic of China; Hainan Key \\ Laboratory of Tropical Oil Crops Biology, Wenchang, Hainan 571339, \\ People's Republic of China; and College of Horticulture, Hainan University, \\ Haikou, Hainan 570228, People's Republic of China
}

\begin{abstract}
Hongxing Cao, Chengxu Sun, and Jerome Jeyakumar John Martin Coconut Research Institute, Chinese Academy of Tropical Agricultural Sciences, Wenchang, Hainan 571339, People's Republic of China; and Hainan Key Laboratory of Tropical Oil Crops Biology, Wenchang, Hainan 571339, People's Republic of China
\end{abstract}

Additional index words. agronomic trait, dwarf genotypes, germplasm, plant breeding, resource assessment

\begin{abstract}
The evaluation and identification of germplasm resources is an indispensable step in the breeding processes and have important roles in the selection and improvement of new varieties. This research intended to characterize coconut germplasm to determine the quantitative, qualitative, and morphological traits of the stem, leaf, and inflorescence and the fruit characteristics. Sixteen morphological and qualitative traits of 17 coconut (Cocos nucifera L.) germplasm resources from Hainan, China, were investigated to determine the characteristics and advantages of multiple germplasm lines to create the foundation for the cultivation and breeding of coconuts. The results of the correlation analysis, principal component analysis (PCA), and cluster analysis indicate a correlation between coconut germplasm factors and their contribution to coconut traits. The results revealed that stem girth at $0.2 \mathrm{~m}$ was the most obvious trait, along with the fruit flavor, edible rate, fat content, hole spacing, single fruit weight, and number of female flowers, which reflect most of the information regarding coconut traits and contribute to its value. The PCA and cluster analysis indicated that two high-yield and superior-quality sweet water dwarf coconut germplasms, named ' 15-19' and ' $15-17$ ', were suitable for cultivation and production in Hainan, China. The results of this study act a far-reaching influence on the collection and utilization of coconut resources and have an impact on the development and progress of the coconut industry in China.
\end{abstract}

Coconut (Cocos nucifera L.) is a perennial woody oil crop and food energy crop with tropical characteristics (Lédo et al., 2019; Mao and Qiu, 2006; Wang et al., 2013). Coconuts are widely distributed in tropical regions and have been cultivated for more than 2000 years in China (Ke and Guo, 1994). As the only tropical area, Hainan is the region with the largest coconut planting area in China (Mao and $\mathrm{Fu}, 2011$ ). In other provinces such as Guangdong, Guangxi, Yunnan, and Taiwan, it distributed sporadically (Chen et al., 2011). Additionally,

Received for publication 1 Apr. 2021. Accepted for publication 8 June 2021.

Published online 9 July 2021.

This research was supported by the project of Key R\&D Program of Hainan Province (ZDYF2019040).

H.C. and C.S. are the corresponding authors. E-mail: hongxing1976@163.com or SUNCX@live.com.

This is an open access article distributed under the CC BY-NC-ND license (https://creativecommons. org/licenses/by-nc-nd/4.0/). coconut is the provincial tree of Hainan, China. The cultivation, production, processing, utilization, and market sales of Hainan coconuts have a decisive role in the development of the coconut industry in China. As a functional plant, coconut has rich economic value (Udaya et al., 2020). For instance, coconuts have a wide range of nutritional elements, including high contents of protein, fat, and carbohydrates, as well as vitamins and minerals (Zhang, 2011). In addition to their high nutritional value, coconuts have powerful therapeutic (Lima et al., 2015) and ornamental benefits. Coconut water, with its detoxifying and electrolyte-balancing properties, can quickly replenish the water and minerals lost by the human body and is considered a natural injection (Zhang, 2011). As a greening tree species, coconut is often used as a street tree or the main tree species used for landscape design, thus highlighting the beautiful tropical coastal customs (Zhao, 2019). The processing and utilization of coconuts should not be underestimated. It is widely acknowledged that the level of coconut processing in Hainan is relatively advanced, with coconut juice, coconut milk, coconut flower juice, coconut wine, and other processed products or by-products favored and trusted by an increasing number of consumers (Xia et al., 2007; Zhang, 2011). Therefore, researching coconut germplasm resources is of great importance.

The local coconut resources in China are relatively simple. The adaptability studies of introducing germplasm resources from other countries (Li et al., 2009; Sun et al., 2012) have been helpful for addressing issues such as the lack of germplasm resources and difficulty in variety renewal for the Chinese coconut industry. Furthermore, the results of previous studies have helped to facilitate and improve the breeding process. Therefore, the evaluation and identification of coconut germplasm resources have important practical value and innovative significance. Some experts have focused on researching the genetic diversity and genetic performance of coconut germplasm. The genetic analysis of eight coconut germplasm in South Florida has created the foundation for the breeding of local coconut resources (Meerow et al., 2003). Molecular marker technology has been used to analyze the genetic diversity and population structure of coconut resources within a specific range, thereby contributing to the research of coconut germplasm resources on a genetic level (Geethanjali et al., 2017; Preethi et al., 2020; Riangwong et al., 2020). Additionally, the performance and mechanism of ecological adaptation and physiological stress of coconut varieties have been studied (Cao et al., 2014; Hebbar et al., 2020; Pandey and Gupta, 2020; Santos et al., 2020; Yang et al., 2020). The genetic diversity of coconut germplasm provides a basis for the selection of coconut breeding materials and improvements in variety ( $\mathrm{He}$ et al., 2014; Zhou and Cao, 2018). However, there few studies have analyzed and identified the traits of coconut resources. Our research group conducted a preliminary analysis of the ecological adaptability and fruit quality of Vietnamese coconut resources (Cao et al., 2013; Sun et al., 2012). Key factors for evaluating coconut resources were proposed, thereby providing a theoretical basis for the identification and utilization of new germplasm (Sun et al., 2014).

Germplasm resources are the basis of breeding new varieties and germplasm innovation (Liu et al., 2011; Zhang et al., 2021). The identification and evaluation of germplasm traits can promote in-depth development and utilization of resources (Cao et al., 2013; Fan et al., 2015). Because the coconut germplasm resources in China have not been sufficiently evaluated, the determination and analysis of several coconut resource characteristics and traits can help create the foundation for selecting and identifying high-quality resources, which will be beneficial to the exploration and in-depth development of coconut resources in Hainan and other parts of China. Simultaneously, improving the 
coconut market and enhancing the development of the coconut industry in China would

The morphological characteristics (plant height, stem girth, inflorescence length, single fruit weight, etc.) and fruit quality traits (fruit flavor, total sugar, total acids, protein content, etc.) of 17 coconut germplasm resources in Hainan, China, were comprehensively analyzed during this study. The main objective suitable for cultivation in Hainan, China, to provide a theoretical basis for coconut germplasm research. The findings of this study will aid in the breeding of coconut with desirable traits and the formulation of future conservation measures.

\section{Materials and Methods}

\section{Coconut germplasm}

The plant materials used in this experiment were selected from different areas of Hainan Province, China. 'BDL' is the local coconut germplasm line in Hainan, and the other lines are coconuts introduced by and cultivated in other countries (Table 1). All coconut germplasm lines were planted in 2009. All experimental coconuts were distributed in several orchards and plantations in different regions of Hainan. Several sampling regions and related cropping information are shown in Table 2. From all the samples, six well-grown, disease-free coconuts that were 8 years old were considered the testing plant material for each germplasm line.

\section{Morphological traits} germplasm resources of coconut (Cocos nucifera L.) (The Ministry of Agriculture of P.R. China, 2009) and Guidelines for the conduct of tests for distinctness, uniformity and stability of coconut (Cocos nucifera L.) (The Ministry of Agriculture of P.R. China, 2013), parameters such as plant height, leaflet area, stem girth at $0.2 \mathrm{~m}$, leaf scar spacing, inflorescence length, spathe length, and number of be of great significance. was to explore high-quality coconut resources

According to the Descriptors standard for

female flowers were measured. Plant height was determined using a laser range finder (Xuntian AK-1500H, China), and the length indicators were measured with a survey tape.

Single fruit weight was weighed using an electronic balance (MP, Shanghai Jingmi, China) (Sun et al., 2014). Hole spacing was calculated using the vertical distance between the pedicel and flat surface of the coconut shell (Sun et al., 2014). The edible rate was calculated as the ratio of the weight of the edible part to the total weight (Cao et al., 2016).

\section{Fruit quality characteristics}

Eight-month-old fruits were selected as samples. Each plant with 10 fruits was used for each germplasm resource. Fruit quality was determined by the corresponding national standards or previous studies. Testing of each sample was repeated three times.

Fruit flavor. Fruit flavor was evaluated using a previously published scoring method (Sun et al., 2014). The evaluation team was composed of 10 experts and scholars. The fruit flavor grade was evaluated according to the following criteria: 5 points, sweet, sour, delicious, and fruity; 4 points, moderate acidity, moderate sweetness, and fruitiness; 3 points, slightly sour or sweet, slightly fruity; 2 points, light sour and sweet taste, almost no fruitiness; and 1 point, light taste and no fruitiness. The fruit flavor was calculated using the following formula:

Fruit flavor $=\frac{\left.\sum \text { (Scoring point } \times \text { Number of people in each point }\right)}{\text { Total number of people participating in evaluation }}$

Total soluble solids content and total soluble sugar content. The total soluble solids contents were determined using a digital refractometer (ATAGO PAL-1, Japan) (The Ministry of Agriculture of P.R. China, 2014). Based on the relevant national standards (with some revisions), we measured the total soluble sugar contents of fruits using 3,5-dinitrosalicylic acid colorimetry (The Ministry of Agriculture of P.R. China, 2015). We stirred $1 \mathrm{~mL}$ coconut water with potassium ferrocyanide solution (3 $\mathrm{mL})$ and zinc acetate solution $(3 \mathrm{~mL})$; then, the

Table 1. Origin and yield information for several coconut germplasm lines.

\begin{tabular}{lccc}
\hline $\begin{array}{l}\text { Germplasm } \\
\text { line }\end{array}$ & Origin & $\begin{array}{c}\text { Fruit yield } \\
\text { (no. per hectare) }\end{array}$ & $\begin{array}{c}\text { Copra yield }^{\mathrm{z}} \\
\text { (tons per hectare) }\end{array}$ \\
\hline $15-01$ & Indonesia & 26,100 & 2.53 \\
$15-02$ & Vietnam & 27,900 & 2.68 \\
$15-03$ & Thailand & 29,500 & 2.65 \\
$15-10$ & Thailand & 39,700 & 3.31 \\
$15-11$ & Thailand & 27,500 & 3.05 \\
$15-12$ & Thailand & 27,900 & 3.05 \\
$15-13$ & Indonesia & 30,300 & 2.63 \\
$15-14$ & Malaysia & 30,900 & 2.61 \\
$15-15$ & Thailand & 31,600 & 2.74 \\
$15-17$ & Vietnam & 42,900 & 3.82 \\
$15-18$ & Vietnam & 28,800 & 2.64 \\
$15-19$ & Vietnam & 44,400 & 3.89 \\
$15-20$ & Thailand & 31,500 & 2.75 \\
$15-21$ & Thailand & 28,800 & 2.62 \\
$15-99$ & Thailand & 28,200 & 2.64 \\
WY3 & Chinese cultivar (origin & 32,100 & 3.30 \\
& from Malaysia) & & 2.61 \\
BDL & China & 20,400 & \\
\hline
\end{tabular}

${ }^{\mathrm{z}}$ The fruit yield and copra yield are presented as annual production data. mixture was diluted to $25 \mathrm{~mL}$ with distilled water. After filtering, $1 \mathrm{~mL}$ solution with $1 \mathrm{~mL}$ hydrochloric acid solution $(6 \mathrm{~mol} / \mathrm{L})$ was heated at $80^{\circ} \mathrm{C}$ for $10 \mathrm{~min}$. After cooling, the methyl red indicator and sodium hydroxide solution were added until the mixture turned light orange and a constant volume to $25 \mathrm{~mL}$ with distilled water was obtained. Then, $1 \mathrm{~mL}$ solution, $5 \mathrm{~mL}$ distilled water, and $4 \mathrm{~mL} 3,5-$ dinitrosalicylic acid were mixed and heated in a boiling water bath for $5 \mathrm{~min}$. The absorbance of the mixed solution was measured at $540 \mathrm{~nm}$ with an ultraviolet-VIS spectrophotometer (ultraviolet-1600, Shanghai Aoyi, China) after cooling; then, the total soluble sugar content was calculated. The standard curve was obtained from the glucose standard solution and the content was expressed as a percent.

Total acids content. The total acids contents were assayed according to the National Food Safety Standard: Determination of Acid Value in Food (National Health and Family Planning Commission of P.R. China, 2016) with slight modifications. A fresh coconut water sample (1 $\mathrm{mL})$, ether-isopropanol mixture $(5 \mathrm{~mL})$, and phenolphthalein indicator were thoroughly mixed until they dissolved. The sodium hydroxide solution $(0.1 \mathrm{~mol} / \mathrm{L})$ was used for titration until the solution appeared reddish and did not fade within $15 \mathrm{~s}$. The volume of the standard solution consumed in the titration was recorded, and the total acids content was calculated and presented as a percentage.

Fat content. Based on the Aoi Soxhlet extractor method (National Health and Family Planning Commission of P.R. China and National Foods and Medical Products Administration, 2016b) with slight modifications, the fat contents of the tested fruits were determined. Dried copra samples (2 g) were placed in the Soxhlet extraction system (Soxtec 8000 , FOSS, Scandinavia) for heating and reflux extraction with $80 \mathrm{~mL}$ petroleum ether (boiling range, 30 to $60^{\circ} \mathrm{C}$ ). The extraction was continued for $3 \mathrm{~h}$. The sample was dried at $105^{\circ} \mathrm{C}$ for $1 \mathrm{~h}$ and weighed after cooling. This procedure was repeated until the weight reached a constant. The fat content was calculated using the difference in weight and expressed as a percent.

Protein content. The protein contents of the tested coconut germplasm resources were measured based on the National Food Safety Standard: Determination of Protein in Food (National Health and Family Planning Commission of P.R. China and National Foods and Medical Products Administration, 2016a) with slight modifications. After degreasing, the dried copra samples ( $1 \mathrm{~g})$ were mixed with $0.1 \mathrm{~g}$ copper sulfate, $1 \mathrm{~g}$ potassium sulphate, and $10 \mathrm{~mL}$ sulfuric acid solution. The mixture was heated when it was fully carbonized and the liquid was slightly boiled. After the solution turned a clear blue-green color, the mixture was heated for another 30 $\mathrm{min}$. The solution was removed and brought to a constant volume with distilled water ( 50 $\mathrm{mL})$ after cooling. The mixture $(3 \mathrm{~mL})$ was mixed with p-nitrophenol and sodium hydroxide solution to give it a yellow appearance. Then, acetic acid was added to make the 


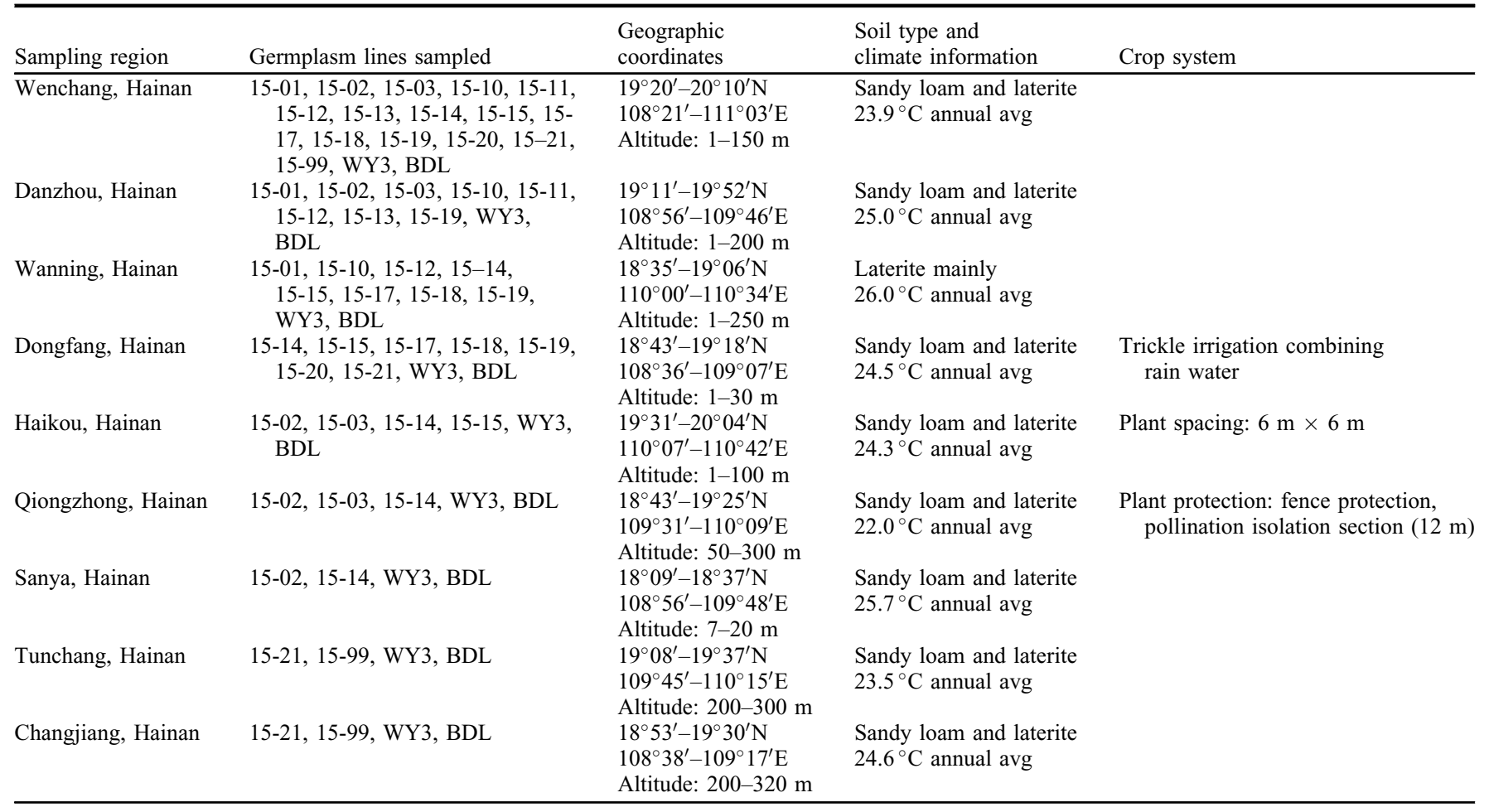

solution colorless; distilled water was added to achieve a metered volume $(10 \mathrm{~mL})$. Then, 1 $\mathrm{mL}$ mixture, $4 \mathrm{~mL}$ buffer solution containing sodium acetate and acetic acid, $4 \mathrm{~mL}$ color developing agent containing methanal and acetylacetone, and $1 \mathrm{~mL}$ distilled water were mixed and heated in a water bath $\left(100^{\circ} \mathrm{C}\right)$ for $15 \mathrm{~min}$. After cooling, the absorbance value was measured at $400 \mathrm{~nm}$. The standard curve was developed using ammonium sulfate standard solution. The content value was defined as a percentage.

\section{Data and statistical analysis}

All measurements were repeated three times during this experiment. The data are presented as the mean \pm SD $(n=3)$. The differences between treatments were analyzed using a one-way analysis of variance, and the significant differences among means were identified by Duncan's test at $P=0.05$ and $P=0.01$ with SPSS software (version 19.0; IBM, Armonk, NY). A correlation analysis, PCA, and cluster analysis were performed using Data Processing System (DPS).

\section{Results and Discussion}

\section{Performance of tree morphological features}

The morphological characteristics of 17 coconut resources in Hainan are shown in Table 3. Among all the tested lines, plant height, leaflet area, and stem girth at $0.2 \mathrm{~m}$ of

Table 3. Tree morphological features of 17 coconut germplasm lines.

\begin{tabular}{llccc}
\hline $\begin{array}{l}\text { Resource } \\
\text { number }\end{array}$ & Plant ht $(\mathrm{m})$ & Leaflet area $\left(\mathrm{dm}^{2}\right)$ & $\begin{array}{c}\text { Stem girth } \\
\text { at } 0.2 \mathrm{~m}(\mathrm{~m})\end{array}$ & Leaf scar spacing $(\mathrm{cm})$ \\
\hline $15-01$ & $7.62 \pm 0.15 \mathrm{~b}$ & $14.47 \pm 0.75 \mathrm{~b}$ & $1.08 \pm 0.19 \mathrm{de}$ & $1.00 \pm 0.15 \mathrm{abc}$ \\
$15-02$ & $6.19 \pm 0.14 \mathrm{def}$ & $9.33 \pm 0.51 \mathrm{c}$ & $1.07 \pm 0.17 \mathrm{e}$ & $0.71 \pm 0.11 \mathrm{de}$ \\
$15-03$ & $4.70 \pm 0.17 \mathrm{efg}$ & $5.23 \pm 0.52 \mathrm{fgh}$ & $1.08 \pm 0.16 \mathrm{de}$ & $0.81 \pm 0.15 \mathrm{cde}$ \\
$15-10$ & $4.83 \pm 0.14 \mathrm{def}$ & $5.58 \pm 0.67 \mathrm{efg}$ & $0.84 \pm 0.12 \mathrm{~g}$ & $0.67 \pm 0.14 \mathrm{de}$ \\
$15-11$ & $7.25 \pm 0.13 \mathrm{c}$ & $12.96 \pm 0.63 \mathrm{~b}$ & $1.13 \pm 0.17 \mathrm{c}$ & $0.73 \pm 0.18 \mathrm{de}$ \\
$15-12$ & $7.20 \pm 0.18 \mathrm{~cd}$ & $6.00 \pm 0.53 \mathrm{efg}$ & $0.94 \pm 0.16 \mathrm{f}$ & $1.03 \pm 0.15 \mathrm{abc}$ \\
$15-13$ & $4.50 \pm 0.18 \mathrm{fg}$ & $5.66 \pm 0.45 \mathrm{efg}$ & $0.96 \pm 0.14 \mathrm{f}$ & $0.68 \pm 0.14 \mathrm{de}$ \\
$15-14$ & $4.45 \pm 0.13 \mathrm{gh}$ & $3.69 \pm 0.53 \mathrm{~h}$ & $1.07 \pm 0.16 \mathrm{e}$ & $0.93 \pm 0.19 \mathrm{bcd}$ \\
$15-15$ & $4.38 \pm 0.11 \mathrm{gh}$ & $7.12 \pm 0.60 \mathrm{de}$ & $1.09 \pm 0.15 \mathrm{cde}$ & $0.99 \pm 0.13 \mathrm{abc}$ \\
$15-17$ & $4.34 \pm 0.16 \mathrm{i}$ & $4.24 \pm 0.41 \mathrm{gh}$ & $0.66 \pm 0.12 \mathrm{i}$ & $0.56 \pm 0.13 \mathrm{e}$ \\
$15-18$ & $5.65 \pm 0.14 \mathrm{def}$ & $5.02 \pm 0.43 \mathrm{fgh}$ & $0.73 \pm 0.12 \mathrm{~h}$ & $0.61 \pm 0.14 \mathrm{e}$ \\
$15-19$ & $4.38 \pm 0.17 \mathrm{~h}$ & $6.72 \pm 0.55 \mathrm{ef}$ & $0.73 \pm 0.16 \mathrm{~h}$ & $0.55 \pm 0.16 \mathrm{e}$ \\
$15-20$ & $4.60 \pm 0.15 \mathrm{efg}$ & $10.34 \pm 0.51 \mathrm{c}$ & $1.19 \pm 0.16 \mathrm{~b}$ & $1.04 \pm 0.14 \mathrm{abc}$ \\
$15-21$ & $6.31 \pm 0.20 \mathrm{~cd}$ & $5.53 \pm 0.54 \mathrm{efg}$ & $1.12 \pm 0.16 \mathrm{~cd}$ & $1.23 \pm 0.17 \mathrm{a}$ \\
$15-99$ & $6.21 \pm 0.17 \mathrm{de}$ & $8.57 \pm 0.58 \mathrm{~cd}$ & $0.97 \pm 0.17 \mathrm{f}$ & $1.08 \pm 0.12 \mathrm{abc}$ \\
WY3 & $4.71 \pm 0.18 \mathrm{def}$ & $9.21 \pm 0.60 \mathrm{c}$ & $0.81 \pm 0.18 \mathrm{~g}$ & $0.56 \pm 0.12 \mathrm{e}$ \\
BDL & $9.82 \pm 0.14 \mathrm{a}$ & $19.01 \pm 0.81 \mathrm{a}$ & $1.43 \pm 0.11 \mathrm{a}$ & $1.16 \pm 0.13 \mathrm{ab}$ \\
\hline
\end{tabular}

Data are represented as the average \pm SD. Different lowercase letters in each column indicate significant difference at $P<0.05$.

Hainan local coconuts ('BDL') were significantly different $(P<0.05)$ from those of other lines. This line was the tallest, with a plant height of $\approx 10 \mathrm{~m}$; this height was 2.26 times that of the dwarf germplasm line ' 15 17'. Although tall coconuts have strong ornamental value (Chen et al., 2005), the larger plant height reflects disadvantages such as difficulty while picking. The heights of the coconut resources imported from other countries were relatively low (Table 3 ), which was greatly significance for improving local coconut germplasm lines and in-depth experimental research. From the perspective of plant height and leaflet area, '15-03', '15-10', '15-13', '15-14', '15-17', and '15-19' manifested dwarf types more suitable for cultivation and experiment. Dwarf coconuts, with a short period of reproductive growth, are able to blossom and yield fruit early, which is crucial for coconut production, processing, and utilization. The leaf scar spacing of the local coconuts was also the largest $(1.16 \mathrm{~cm})$; it was 2.11-times that of the '15-19' germplasm line $(P<0.05)$. Based on the analysis of tree characteristics, '15-13', '15-17', and '15-19' might be defined as the dwarf species of coconuts with the best tree morphological performance.

\section{Performance of inflorescence characters}

It is universally acknowledged that the inflorescence length and the number of buds of coconuts are the key factors determining the yield and quality of the fruit (Feng et al., 2015). The measurement and evaluation of coconut inflorescence traits and characteristics can provide excellent germplasm resources and promote high-yield and high-quality 
Table 4. Inflorescence characteristics of 17 coconut germplasm lines.

\begin{tabular}{lccc}
\hline $\begin{array}{l}\text { Resource } \\
\text { number }\end{array}$ & Inflorescence length $(\mathrm{m})$ & Spathe length $(\mathrm{m})$ & $\begin{array}{c}\text { Number of female } \\
\text { flowers (no.) }\end{array}$ \\
\hline $15-01$ & $1.05 \pm 0.08 \mathrm{abc}$ & $1.08 \pm 0.09 \mathrm{a}$ & $26.67 \pm 0.33 \mathrm{e}$ \\
$15-02$ & $0.92 \pm 0.11 \mathrm{abcd}$ & $0.83 \pm 0.08 \mathrm{abcd}$ & $17.67 \pm 0.33 \mathrm{i}$ \\
$15-03$ & $0.75 \pm 0.10 \mathrm{bcd}$ & $27.67 \pm 0.33 \mathrm{e}$ \\
$15-10$ & $0.61 \pm 0.07 \mathrm{abcd}$ & $0.85 \pm 0.10 \mathrm{abcd}$ & $22.67 \pm 0.33 \mathrm{f}$ \\
$15-11$ & $0.79 \pm 0.09 \mathrm{cde}$ & $0.65 \pm 0.11 \mathrm{~cd}$ & $29.67 \pm 0.33 \mathrm{~d}$ \\
$15-12$ & $1.08 \pm 0.08 \mathrm{ab}$ & $0.96 \pm 0.10 \mathrm{abc}$ & $26.67 \pm 0.33 \mathrm{e}$ \\
$15-13$ & $0.74 \pm 0.09 \mathrm{de}$ & $0.96 \pm 0.11 \mathrm{abc}$ & $27.67 \pm 0.33 \mathrm{e}$ \\
$15-14$ & $0.72 \pm 0.05 \mathrm{de}$ & $0.67 \pm 0.11 \mathrm{~cd}$ & $30.67 \pm 0.33 \mathrm{c}$ \\
$15-15$ & $0.98 \pm 0.09 \mathrm{abcd}$ & $1.00 \pm 0.07 \mathrm{ab}$ & $27.67 \pm 0.33 \mathrm{e}$ \\
$15-17$ & $0.82 \pm 0.09 \mathrm{bcde}$ & $0.66 \pm 0.10 \mathrm{~cd}$ & $34.67 \pm 0.33 \mathrm{a}$ \\
$15-18$ & $0.81 \pm 0.09 \mathrm{bcde}$ & $0.64 \pm 0.07 \mathrm{~d}$ & $27.67 \pm 0.33 \mathrm{e}$ \\
$15-19$ & $0.92 \pm 0.08 \mathrm{abcd}$ & $1.00 \pm 0.10 \mathrm{ab}$ & $33.67 \pm 0.33 \mathrm{~b}$ \\
$15-20$ & $0.91 \pm 0.08 \mathrm{abcd}$ & $1.10 \pm 0.09 \mathrm{a}$ & $26.67 \pm 0.33 \mathrm{e}$ \\
$15-21$ & $0.98 \pm 0.07 \mathrm{abcd}$ & $1.05 \pm 0.08 \mathrm{ab}$ & $26.67 \pm 0.33 \mathrm{e}$ \\
$15-99$ & $0.90 \pm 0.07 \mathrm{abcd}$ & $0.87 \pm 0.09 \mathrm{abcd}$ & $27.67 \pm 0.33 \mathrm{e}$ \\
WY3 & $0.75 \pm 0.08 \mathrm{de}$ & $1.04 \pm 0.09 \mathrm{~d}$ & $20.67 \pm 0.33 \mathrm{~g}$ \\
BDL & $1.12 \pm 0.06 \mathrm{a}$ & $19.67 \pm 0.33 \mathrm{~h}$ \\
\hline
\end{tabular}

Data are represented as average \pm SD. Different lowercase letters in each column indicate significan difference at $P<0.05$.

fruits, which are of great significance to the progress of the coconut market. As shown in Table 4, the inflorescence length, spathe length, and number of female flowers of 17 germplasm lines of coconut resources were studied. Although most resources exhibited similar inflorescence and spathe lengths, there was a significant variation in the number of female flowers $(P<0.05)$. The inflorescence length of the local coconuts in Hainan was the longest $(1.12 \mathrm{~m})$, and the spathe length was also relatively large (1.04 $\mathrm{m})$, but there were few female flowers (19.67), indicating that the local resource of Hainan has certain disadvantages during the flowering and fruiting periods. Research of the coconut inflorescence length, spathe length, stalk length, and number of female flowers has been fascinating. In general, longer inflorescences and buds can provide space for more spicas, thus creating the foundation for fruit development. During production, coconut with longer inflorescences, medium-length spathes, more female flowers, and proper spica spacing manifest the best resources; therefore, more fruits can be produced and fruit development and nutrient accumulation can be accelerated. The number of female flowers has a vital role in coconut production when the lengths of the inflorescence and spathe are similar. A larger number of female flowers was observed for ' 15-17', '15-19', and '15-14' (Table 4); this result was significantly different from that of other germplasm lines. There were obvious differences among these three germplasm lines $(P<0.05)$. Therefore, the coconut germplasm lines '15-17', '15-19', and '15-14' have the potential for high output and exquisite quality during production.

\section{Performance of fruit morphological characteristics}

The fruit morphological characteristics of the test germplasms are shown in Table 5. The fruit weight of the 'BDL' local coconut was the largest $(2.58 \mathrm{~kg} /$ fruit $)$ and significantly higher than that of other germplasm lines; this might be related to the size and height of the tree. However, the large single fruit weight does not indicate the superiority of the resource. The heavier fruit can easily to cause damage when picked or when it is naturally dropped (Zhang et al., 2020). Therefore, the proportions of coconut water and meat as well as the edible rate of the fruit must be considered comprehensively when evaluating coconut germplasm. Hole spacing refers to the vertical distance from the peduncle of the coconut fruit to the plane of the three holes, which is a unique property of coconut fruits. Hole spacing, to a certain extent, can reflect the characteristics of the coconut germplasm itself. As a rule, the hole spacing of the same germplasm line of coconuts is close under the same cultivation conditions and environment, and it will change relatively when affected by the natural environment (for example, drought and cold). Among the 17 coconut resources tested, the differences in hole spacing were quite significant $(P<0.05)$, thus indicating the different characteristics of several coconut resources (Table 5). The hole spacing of '15difference at $P<0.05$.
10 ' reached $8.25 \mathrm{~cm}$, and the smallest hole spacing was only $1.83 \mathrm{~cm}$ (' $15-14$ '). Sometimes the size of the hole spacing is associated with the labor of opening fresh coconuts.

The edible rates of ' $15-19$ ', ' $15-18$ ', ' 15 13 ', and ' $15-17$ ' were all relatively high, especially that of ' $15-19$ ', which reached $53.18 \%$; this value was 2.09 -times that of the ' $15-10$ ' germplasm line. Many researchers have focused on the fresh-eating, processing, and utilization of coconuts (Kabir et al., 2020; Lei et al., 2020); therefore, the edible rate is an important manifestation of the edibility and processed quality of coconuts. The popularity and acceptance levels of ' $15-03$ ', ' $15-12$ ', and ' $15-02$ ' lines with large single fruit weight and low edible rate as well as those of ' $15-10$ ' with an extremely low edible rate on the market are relatively restricted. Scaling production is not recommended. Based on the analysis of these morphological factors, the lines ' $15-19$ ' and ' $15-17$ ', which have a modest fruit weight but a high edible rate, were relatively suitable for quantity production and market circulation of germplasm resources.

\section{Performance of fruit quality traits}

As a natural beverage and sports drink (Deng et al., 2018), the natural food quality, processing quality, and regulation of coconut have been favored by consumers and have gained the attention of researchers (Antu et al., 2014; Geng et al., 2017; Khathir et al., 2021; Raghubeer et al., 2020; Sarkar et al., 2020). Hence, research of the fruit quality of coconut resources will create the foundation for the breeding of high-quality new varieties and the improvement of fruit quality. The fruit flavor, total soluble solids, total acids, total soluble sugar contents, protein content, and fat content of the experimental coconuts were investigated (Table 6). Fruit flavors of most resources were significantly different $(P<0.05)$; ' $15-19$ ' had the best, followed by ' $15-21$ ', 'BDL', and '15-01'. Fruit flavor is an important evaluation index for fresh coconuts, and types with prominent flavor, such as ' $15-19$ ' and ' $15-21$ ', have the potential for

Table 5. Fruit morphological characteristics of 17 coconut germplasm lines.

\begin{tabular}{lccc}
\hline Resource number & Single fruit $\mathrm{wt}(\mathrm{kg})$ & Hole spacing $(\mathrm{cm})$ & Edible rate $(\%)$ \\
\hline $15-01$ & $1.03 \pm 0.11 \mathrm{f}$ & $4.77 \pm 0.09 \mathrm{e}$ & $45.67 \pm 0.10 \mathrm{~h}$ \\
$15-02$ & $2.18 \pm 0.08 \mathrm{~b}$ & $4.39 \pm 0.09 \mathrm{e}$ & $42.64 \pm 0.08 \mathrm{k}$ \\
$15-03$ & $2.21 \pm 0.07 \mathrm{~b}$ & $5.56 \pm 0.09 \mathrm{~d}$ & $32.55 \pm 0.09 \mathrm{n}$ \\
$15-10$ & $1.53 \pm 0.10 \mathrm{e}$ & $8.25 \pm 0.08 \mathrm{a}$ & $25.39 \pm 0.09 \mathrm{o}$ \\
$15-11$ & $1.47 \pm 0.07 \mathrm{e}$ & $6.17 \pm 0.09 \mathrm{bc}$ & $44.15 \pm 0.09 \mathrm{i}$ \\
$15-12$ & $2.07 \pm 0.08 \mathrm{bc}$ & $3.59 \pm 0.09 \mathrm{f}$ & $38.13 \pm 0.08 \mathrm{~m}$ \\
$15-13$ & $1.10 \pm 0.07 \mathrm{f}$ & $4.64 \pm 0.08 \mathrm{e}$ & $50.61 \pm 0.07 \mathrm{~b}$ \\
$15-14$ & $1.94 \pm 0.09 \mathrm{bc}$ & $1.83 \pm 0.71 \mathrm{~h}$ & $41.36 \pm 0.091$ \\
$15-15$ & $1.66 \pm 0.09 \mathrm{de}$ & $3.65 \pm 0.09 \mathrm{f}$ & $49.17 \pm 0.09 \mathrm{~d}$ \\
$15-17$ & $0.70 \pm 0.11 \mathrm{~g}$ & $6.57 \pm 0.07 \mathrm{~b}$ & $50.15 \pm 0.08 \mathrm{c}$ \\
$15-18$ & $1.12 \pm 0.09 \mathrm{f}$ & $5.70 \pm 0.11 \mathrm{~cd}$ & $50.67 \pm 0.09 \mathrm{~b}$ \\
$15-19$ & $0.71 \pm 0.09 \mathrm{~g}$ & $4.93 \pm 0.09 \mathrm{e}$ & $53.18 \pm 0.11 \mathrm{a}$ \\
$15-20$ & $1.60 \pm 0.10 \mathrm{de}$ & $2.65 \pm 0.09 \mathrm{~g}$ & $43.69 \pm 0.11 \mathrm{j}$ \\
$15-21$ & $1.85 \pm 0.10 \mathrm{~cd}$ & $5.52 \pm 0.09 \mathrm{~d}$ & $48.19 \pm 0.11 \mathrm{f}$ \\
$15-99$ & $2.00 \pm 0.10 \mathrm{bc}$ & $4.74 \pm 0.07 \mathrm{e}$ & $45.68 \pm 0.10 \mathrm{~h}$ \\
WY3 & $1.10 \pm 0.08 \mathrm{f}$ & $4.65 \pm 0.09 \mathrm{e}$ & $48.46 \pm 0.09 \mathrm{e}$ \\
BDL & $2.58 \pm 0.08 \mathrm{a}$ & $3.42 \pm 0.09 \mathrm{f}$ & $46.63 \pm 0.08 \mathrm{~g}$ \\
\hline Data & & &
\end{tabular}

Data are represented as average \pm SD. Different lowercase letters in each column indicate significant 
Table 6. Evaluation of the fruit quality of 17 coconut germplasm lines.

\begin{tabular}{|c|c|c|c|c|c|c|}
\hline $\begin{array}{l}\text { Resource } \\
\text { number }\end{array}$ & Fruit flavor & $\begin{array}{c}\text { Total soluble } \\
\text { solids content }(\%)\end{array}$ & $\begin{array}{l}\text { Total acids } \\
\text { content }(\%)\end{array}$ & $\begin{array}{c}\text { Total soluble } \\
\text { sugar content }(\%)\end{array}$ & $\begin{array}{c}\text { Protein } \\
\text { content }(\%)\end{array}$ & $\begin{array}{c}\text { Fat } \\
\text { content }(\%)\end{array}$ \\
\hline $15-01$ & $4.99 \pm 0.09 \mathrm{a}$ & $7.15 \pm 0.09 \mathrm{a}$ & $0.55 \pm 0.08 \mathrm{a}$ & $3.03 \pm 0.09 \mathrm{~d}$ & $3.52 \pm 0.10 b$ & $10.32 \pm 0.09 \mathrm{~h}$ \\
\hline $15-02$ & $4.17 \pm 0.09 \mathrm{~cd}$ & $5.95 \pm 0.08 \mathrm{~d}$ & $0.51 \pm 0.08 \mathrm{a}$ & $3.02 \pm 0.08 \mathrm{~d}$ & $3.70 \pm 0.07 \mathrm{~b}$ & $15.24 \pm 0.10 \mathrm{c}$ \\
\hline $15-03$ & $4.17 \pm 0.10 \mathrm{~cd}$ & $6.24 \pm 0.09 \mathrm{c}$ & $0.52 \pm 0.09 \mathrm{a}$ & $3.42 \pm 0.08 \mathrm{c}$ & $3.74 \pm 0.07 \mathrm{~b}$ & $15.93 \pm 0.11 b$ \\
\hline $15-10$ & $3.68 \pm 0.10 \mathrm{e}$ & $4.33 \pm 0.08 \mathrm{gh}$ & $0.56 \pm 0.07 \mathrm{a}$ & $2.73 \pm 0.09 \mathrm{e}$ & $2.89 \pm 0.10 \mathrm{c}$ & $11.17 \pm 0.08 \mathrm{f}$ \\
\hline $15-11$ & $4.94 \pm 0.07 \mathrm{a}$ & $4.27 \pm 0.10 \mathrm{~h}$ & $0.48 \pm 0.08 \mathrm{a}$ & $3.50 \pm 0.08 \mathrm{c}$ & $4.52 \pm 0.10 \mathrm{a}$ & $15.19 \pm 0.09 \mathrm{c}$ \\
\hline $15-12$ & $3.67 \pm 0.09 \mathrm{e}$ & $6.91 \pm 0.08 \mathrm{a}$ & $0.48 \pm 0.09 \mathrm{a}$ & $4.01 \pm 0.08 \mathrm{~b}$ & $3.13 \pm 0.10 \mathrm{c}$ & $18.37 \pm 0.09 \mathrm{a}$ \\
\hline $15-13$ & $3.99 \pm 0.10 \mathrm{~d}$ & $5.68 \pm 0.11 \mathrm{e}$ & $0.46 \pm 0.08 \mathrm{a}$ & $3.58 \pm 0.09 \mathrm{c}$ & $3.46 \pm 0.09 b$ & $18.32 \pm 0.09 \mathrm{a}$ \\
\hline $15-14$ & $3.68 \pm 0.10 \mathrm{e}$ & $4.59 \pm 0.11 \mathrm{~g}$ & $0.45 \pm 0.08 \mathrm{a}$ & $3.54 \pm 0.09 \mathrm{c}$ & $2.84 \pm 0.08 \mathrm{c}$ & $9.15 \pm 0.09 \mathrm{j}$ \\
\hline $15-15$ & $3.50 \pm 0.09$ ef & $3.81 \pm 0.11 \mathrm{i}$ & $0.54 \pm 0.06 \mathrm{a}$ & $2.73 \pm 0.08 \mathrm{e}$ & $1.50 \pm 0.09 \mathrm{e}$ & $10.88 \pm 0.10 \mathrm{~g}$ \\
\hline $15-17$ & $4.34 \pm 0.09 \mathrm{c}$ & $6.63 \pm 0.08 b$ & $0.50 \pm 0.09 \mathrm{a}$ & $3.57 \pm 0.09 \mathrm{c}$ & $3.01 \pm 0.09 \mathrm{c}$ & $13.51 \pm 0.10 \mathrm{~d}$ \\
\hline $15-18$ & $3.65 \pm 0.09 \mathrm{e}$ & $6.93 \pm 0.09 \mathrm{a}$ & $0.49 \pm 0.09 \mathrm{a}$ & $3.97 \pm 0.10 \mathrm{~b}$ & $2.41 \pm 0.09 \mathrm{~d}$ & $18.56 \pm 0.07 \mathrm{a}$ \\
\hline $15-19$ & $5.00 \pm 0.07 \mathrm{a}$ & $7.04 \pm 0.10 \mathrm{a}$ & $0.49 \pm 0.08 \mathrm{a}$ & $4.03 \pm 0.08 \mathrm{ab}$ & $3.59 \pm 0.10 b$ & $4.07 \pm 0.10 \mathrm{k}$ \\
\hline $15-20$ & $3.36 \pm 0.11 \mathrm{f}$ & $3.73 \pm 0.08 \mathrm{i}$ & $0.53 \pm 0.09 \mathrm{a}$ & $2.27 \pm 0.09 \mathrm{f}$ & $1.27 \pm 0.09 \mathrm{c}$ & $10.02 \pm 0.09 \mathrm{i}$ \\
\hline $15-21$ & $5.00 \pm 0.10 \mathrm{a}$ & $6.39 \pm 0.07 \mathrm{bc}$ & $0.61 \pm 0.09 \mathrm{a}$ & $4.28 \pm 0.10 \mathrm{a}$ & $2.98 \pm 0.09 \mathrm{c}$ & $11.54 \pm 0.08 \mathrm{e}$ \\
\hline $15-99$ & $3.63 \pm 0.08 \mathrm{ef}$ & $4.35 \pm 0.09 \mathrm{gh}$ & $0.58 \pm 0.09 \mathrm{a}$ & $2.69 \pm 0.07 \mathrm{e}$ & $2.91 \pm 0.11 \mathrm{c}$ & $11.18 \pm 0.09 \mathrm{f}$ \\
\hline WY3 & $4.67 \pm 0.10 b$ & $5.37 \pm 0.08 \mathrm{f}$ & $0.48 \pm 0.07 \mathrm{a}$ & $4.01 \pm 0.08 \mathrm{~b}$ & $3.70 \pm 0.10 b$ & $9.26 \pm 0.11 \mathrm{j}$ \\
\hline BDL & $5.00 \pm 0.09 \mathrm{a}$ & $6.39 \pm 0.08 \mathrm{bc}$ & $0.59 \pm 0.07 \mathrm{a}$ & $4.24 \pm 0.09 \mathrm{ab}$ & $3.02 \pm 0.10 \mathrm{c}$ & $11.57 \pm 0.10 \mathrm{e}$ \\
\hline
\end{tabular}

Data are represented as average \pm SD. Different lowercase letters in each column indicate significant difference at $P<0.05$.

large-scale cultivation as fresh food. It has been concluded that the fruit flavor of coconuts is related to its corresponding enzyme activity (Campos et al., 1996); therefore, altering the enzyme activity for flavor quality improvement of poorly performing resources, such as '15-20', '15-99', an '15-18', could be an interesting undertaking. The total soluble solids, total acids, and total sugar are of great significance to the edible quality of coconuts, whether fresh or processed, and can directly reflect the sweet and sour tastes of coconut fruits; they are also the most crucial factors in market sales. The '15-01', '15-19', '15-18', and ' $15-17$ ' germplasms had better performance (Table 6) and could be used for genetic improvement of varieties with poor sour and sweet qualities. Protein and fat contents are economic indicators of importance for coconut fruits, especially for processed coconuts (Cao et al., 2013; Mepba and Achinewhu, 2003). The '15-13', '15-12', '15-03' and ' $15-02$ ' germplasms have high protein and fat contents; therefore, they have great potential for utilization in coconut processing. Coconut oil is dependent on the fat content of the coconut fruit, and its quality regulation has been the focus of many studies (Liu et al., 2019; Parlindungan et al., 2020; Wijayati et al., 2019). Therefore, the determination and analysis of the fat content in coconut fruits are crucial to coconut oil processing and research. The qualities of different germplasm lines could lead to differences in the qualities of processed products; a germplasm with a high fat content could contribute to preferable virgin coconut oil quality (Hanjaya et al., 2020; Mulyadi et al., 2019), which is of great significance to its processing and utilization.

The superiority of coconut fruits needs to be comprehensively analyzed through multiple indicators, such as flavor quality, taste quality, protein content, and fat content. The '15-19' germplasm line has low protein and fat contents but extremely high flavor quality and eating quality (Table 6); therefore, it is an excellent fresh food that needs attention.
The '15-17', '15-03', and '15-02' germplasms have high protein and fat contents as well as medium-to-high edible quality; therefore, they could be used as resources for both fresh food and processing. The quality indicators of '15-14' are not outstanding; therefore, large-scale cultivation and production are not necessary. According to the quality characteristics of diverse germplasms, different economic values and purposes can be realized, thus providing certain references and a theoretical basis for the coconut industry and processing industry.

\section{Correlation analysis}

Results of the correlation analysis and comparison of 10 morphological characteristics and 6 quality traits of 17 coconut germplasm resources are shown in Table 7 . In general, correlation coefficient values near 1 or -1 represent a strong relationship between the variables (Schober et al., 2018). The relevance of plant growth, to a certain extent, can efficiently predict the period of fruit development. Stem girth at $0.2 \mathrm{~m}$ had an extremely significant positive correlation with inflorescence length and spathe length, thus embodying the relevance between vegetative growth and reproductive growth ( $\mathrm{Li}$ and Zhang, 2012; Wang et al., 2019). The stem girth at $0.2 \mathrm{~m}$ can sometimes predict flower growth. Also, stem girth at $0.2 \mathrm{~m}$ had a higher positive correlation with leaf scar spacing $(\mathrm{r}=$ $0.75)$ and single fruit weight $(r=0.73)$ (Table 7), indicating that stem girth at $0.2 \mathrm{~m}$ can provide an estimation of the fruit weight. Therefore, stem girth at $0.2 \mathrm{~m}$ is an important reflection of flower and fruit properties and the yield of coconuts. Leaf scar spacing had a moderate and extremely significantly positive correlation with inflorescence length, spathe length, single fruit weight, and total soluble sugar content; therefore, leaf scar spacing can be used to understand the fruit weight and quality. Leaflet area, which had a significantly positive correlation with inflorescence length $(r=0.50)$ and fruit flavor $(r=0.48)$, could also reflect flower and fruit quality. It was obvious that the inflorescence length had a certain correlation with spathe length, and its significantly positive correlations with spathe length and total soluble sugar content are beneficial. The morphological traits of coconuts, including stem girth at $0.2 \mathrm{~m}$, leaf scar spacing, leaflet area, and inflorescence length, could represent the fruit yield and quality to some extent.

Regarding the coconut fruit traits, the results of the correlation analysis could help determine the fruit flavor formation and related contributors. The total soluble solids content appeared to have a significantly positive correlation with fruit flavor $(r=0.5)$, thereby showing the effect of the total soluble solids content on the taste quality of fruits. Similarly, the total acids content contributed to the formation of fruit flavor $(r=$ 0.57 ). It is worth noting that the protein content has a significantly positive correlation with fruit flavor, indicating that the fruit tasting quality and edible quality are not only related to the sugar and acid contents. Some nutrients, like protein, also contributed greatly to the formation of fruit flavor. Therefore, the protein content could be considered a significant criteria for breeding new varieties for fresh-eating and processing.

Some experimental characteristics were not significant, possibly because of their lesser contribution to the development or genetic composition (Maji and Shaibu, 2012), in germplasm resources tested. The positive and significant association of the indicators will provide an understanding of the phenotypic characteristics and the degree of correlation, thus allowing the planning of breeding schemes and management of plant germplasms. According to the correlations of different morphological traits and physiological indicators, sometimes the fruit morphology and quality characteristics of coconut resources can be predicted. In general, the results of the correlation analysis of various morphological characteristics and fruit quality traits of coconuts can provide helpful information regarding the selection, cultivation, and production of coconut germplasm resources. 
Table 7. Correlation analysis of morphological, inflorescence, and fruit characteristics and quality traits.

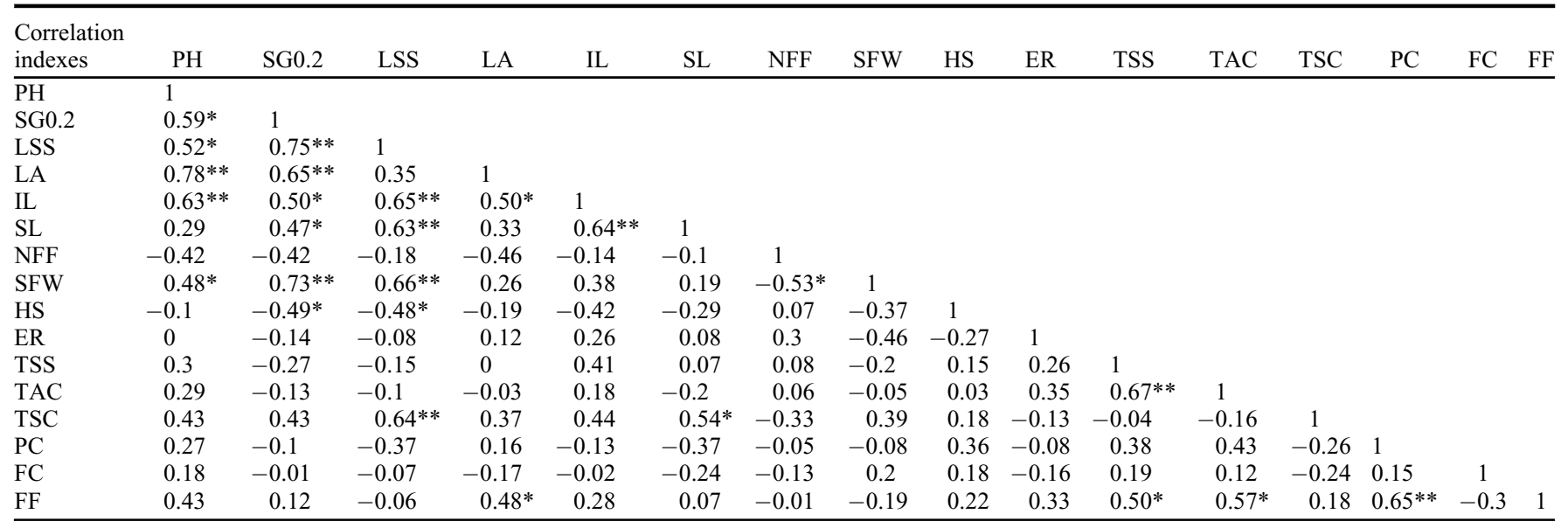

*, **Significant $(P<0.05)$ positive correlation and extremely significant $(P<0.01)$ positive correlation, respectively.

$\mathrm{ER}=$ edible rate; $\mathrm{FC}=$ fat content; $\mathrm{FF}=$ fruit flavor; $\mathrm{HS}=$ hole spacing; $\mathrm{IL}=$ inflorescence length; $\mathrm{LA}=$ leaflet area; $\mathrm{LSS}=$ leaf scar spacing; NFF $=$ number of female flowers; $\mathrm{PC}=$ protein content; $\mathrm{PH}=$ plant height; $\mathrm{SG} 0.2=$ stem girth at $0.2 \mathrm{~m} ; \mathrm{SFW}=$ single fruit weight; $\mathrm{SL}=$ spathe length; TAC = total acids content; TSC $=$ total soluble sugar content; TSS $=$ total soluble solids content.

\section{Principal component analysis}

PCA can simplify multiple indicators using comprehensive factors for analysis and evaluation (Kong et al., 2005). The application of PCA is conducive to exploring the factors that contribute to the understanding and evaluation of crop characteristics and can directly assist improvements in plant varieties and breeding new varieties (Suzana et al., 2020). PCA and investigation were performed for 16 varieties (Table 8). It was shown that the first seven principal components contributed significant data, with a cumulative contribution rate of $90.8 \%$, that accurately reflected the morphological and quality traits of coconut germplasms. Stem girth at $0.2 \mathrm{~m}$ (first principal component) showed a positive value and had the highest contribution rate $(31.5 \%)$, which accounted for nearly one-third of the total contribution value. Therefore, it is clear that stem girth at $0.2 \mathrm{~m}$ has an important role in the evaluation and research of coconut germplasm resources. The fruit flavor (second principal component) and edible rate (third principal component) also had high positive values, and their contribution rates were $20.22 \%$ and $13.12 \%$, respectively. Important factors for the fresh-eating and processing of coconuts (Cancel et al., 1976; Wang et al., 2020) are flavor and the edible rate, which had relatively high values; therefore, their relevance may be exhibited by the market circulation. The fat content (fourth principal component), which reflects the fruit processing character, was also high. Hole spacing (fifth principal component) is an important characteristic of coconut fruit that has a significant effect on the differentiation of coconut germplasm lines; it displayed a positive value. Single fruit weight (sixth principal component) and the number of female flowers (seventh principal component) better reflected the characteristics of coconut inflorescence and fruit and provided a reference index for the identification of coconut resources. Information regarding coconut morphological traits and quality characteristics can be more comprehensively summarized and represented by these seven principal components. These component can be used to simplify evaluations and provide a theoretical basis for subsequent exploration and research of coconut germplasms. In other words, the five morphological characteristics (stem girth at 0.2 $\mathrm{m}$, hole spacing, number of female flowers, single fruit weight, and edible rate) and two quality characteristics (fruit flavor and fat content) can collectively show the basic features of coconut germplasms. The results can contribute to accelerating the process of coconut germplasm evaluation and variety selection in China.

\section{Cluster analysis}

A hierarchical clustering analysis is efficient and widely used for germplasm evaluation and quality assessment (Saraçli et al., 2013). In this study, a cluster analysis of 10 agricultural characteristics and six quality traits of 17 coconut germplasms was performed. Four major clusters were formed in a dendrogram created based on the clustering method based on Euclidean distance (Fig. 1A). The first cluster consisted of several characteristics, and the other clusters contained only one trait. One branch included fruit

Table 8. Principal component (PC) analysis of morphological, inflorescence, and fruit characteristics and quality traits.

\begin{tabular}{|c|c|c|c|c|c|c|c|c|}
\hline Measurement indexes & $\mathrm{PC} 1$ & $\mathrm{PC} 2$ & PC3 & PC4 & PC5 & PC6 & PC7 & PC8 \\
\hline Plant height & 0.34 & 0.26 & -0.18 & 0.04 & 0 & -0.17 & 0.16 & 0.13 \\
\hline Stem girth at $0.2 \mathrm{~m}$ & 0.39 & -0.08 & -0.09 & 0.04 & -0.25 & 0.1 & 0.22 & 0.07 \\
\hline Leaf scar spacing & 0.38 & -0.13 & 0.11 & 0.1 & 0.15 & 0.26 & 0.16 & 0.22 \\
\hline Inflorescence length & 0.34 & 0.16 & 0.22 & 0.18 & 0.19 & -0.09 & 0.05 & -0.2 \\
\hline Spathe length & 0.29 & -0.06 & 0.31 & -0.12 & 0.27 & -0.09 & 0.08 & -0.45 \\
\hline Number of female flowers & -0.22 & 0.02 & 0.38 & 0.06 & 0.13 & 0.3 & 0.71 & 0.14 \\
\hline Single fruit weight & 0.31 & -0.15 & -0.31 & 0.23 & 0 & 0.34 & -0.1 & 0.07 \\
\hline Total soluble solids content & -0.01 & 0.44 & 0.07 & 0.21 & 0.37 & -0.01 & -0.18 & -0.35 \\
\hline Total acids content & -0.02 & 0.43 & 0.01 & 0.29 & 0.04 & 0.33 & -0.31 & 0.29 \\
\hline Total soluble sugar content & 0.3 & -0.04 & 0.01 & -0.4 & 0.4 & 0.06 & -0.17 & 0.36 \\
\hline Protein content & -0.08 & 0.39 & -0.33 & -0.08 & -0.2 & 0.21 & 0.29 & -0.23 \\
\hline Fat content & -0.04 & 0.02 & -0.37 & 0.49 & 0.29 & -0.43 & 0.3 & 0.16 \\
\hline Fruit flavor & 0.08 & 0.48 & 0.05 & -0.29 & -0.14 & 0.19 & 0.06 & 0.02 \\
\hline Contribution rate (\%) & 31.5 & 20.22 & 13.12 & 9.44 & 7.68 & 4.86 & 3.97 & 3.43 \\
\hline
\end{tabular}



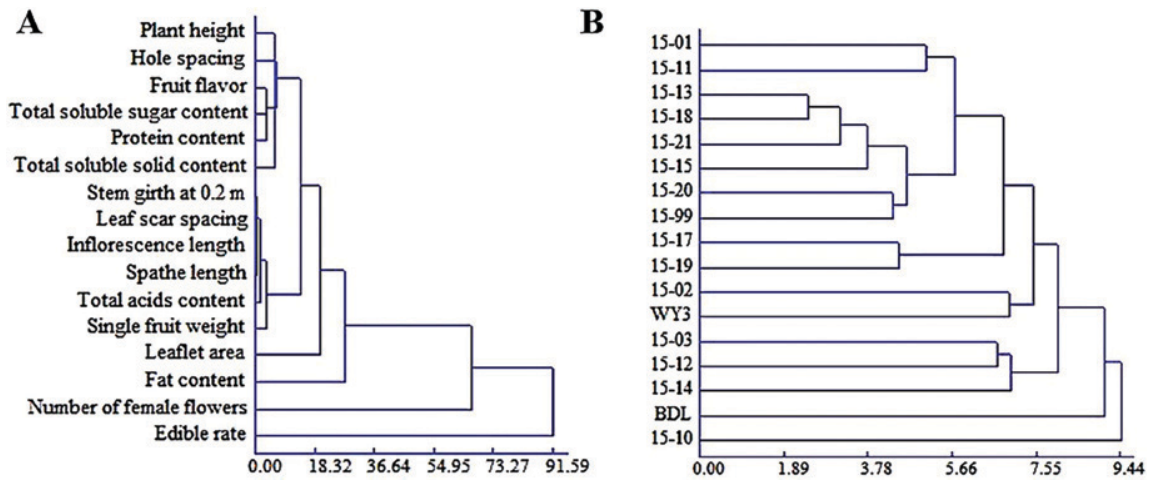

Fig. 1. Cluster analysis of coconut morphological traits and fruit quality characteristics (A) and 17 coconut germplasm lines $(\mathbf{B})$

flavor, total soluble sugar content, and protein content (all quality indicators), which are associated with the aforementioned correlation analysis. Plant height, hole spacing, and total soluble solids content were also included in this branch and had similar coconut characteristic performance. Another branch included stem girth at $0.2 \mathrm{~m}$, leaf scar spacing, inflorescence length, spathe length, total acids content, and single fruit weight (all morphological traits). The two branches and leaflet area formed the first cluster together and contained most of the test indicators. In the first cluster, appearance characteristics, such as plant height, stem girth at $0.2 \mathrm{~m}$, leaf scar spacing, and single fruit weight, were identified as one category (Fig. 1A) with significant positive correlations that indicated their relationship with the growth of different organs. Internal indicators such as fruit flavor, total soluble sugar content, protein content, total soluble solids content, and total acids content were defined as one classification; however, fruit flavor was correlated with many factors (Table 7), thus proving its ability to represent fruit quality. The same conclusion obtained from PCA was obtained from the cluster analysis. Fat content is an important coconut processing trait that occupied the second cluster; it embodies the significance of fat in coconuts and provides a valuable reference for assessing coconut quality and variety breeding. PCA indicated that the fat content is the main evaluation index for cultivar identification. The number of female flowers and edible rate were in the third cluster and fourth cluster, respectively, indicating that these two indicators are not similar and are different from the others.

Figure 1B shows the cluster analysis results of 17 experimental coconut germplasm lines. Based on Euclidean distance, four major groups were established in a dendrogram, with 'BDL' and '15-10' each in their own cluster. The third cluster contained '15-03', '15-12', and '15-14'. All other germplasm lines presented as a cluster. Germplasms ' $15-17$ ' and ' $15-19$ ' were grouped together, as were ' 15 02 ' and 'WY3'. 'BDL' was clustered into a single cluster and had low similarity with other germplasm lines; it also had low performance regarding morphological characteristics and quality traits. Germplasms ' $15-03$ ' and ' $15-12$ ' had large single fruit weights, low edible rates, and high protein and fat contents; therefore, these were clustered into one category. During a previous analysis, '15-19' and '15-17' had a similar tree, inflorescence, and fruit morphological characteristics; they also had the best fruit quality performance. These two had similar morphological and quality presentations.

The results of the correlation analysis, PCA, and cluster analysis exhibited clear similarities, indicating the relative accuracy of the conclusion of this study. The fat content, number of female flowers and edible rate, which had different levels than other traits in the cluster analysis, notably contributed to the experimental characteristics in PCA. The correlation analysis indicated that plant height, stem girth at $0.2 \mathrm{~m}$, leaf scar spacing, and single fruit weight had certain relevance and had similar levels in the cluster analysis. Overall, it was determined that stem girth at $0.2 \mathrm{~m}$, fruit flavor, edible rate, fat content, hole spacing, single fruit weight, and number of female flowers could predict the coconut germplasm evaluation and assessment results. Using these indicators as a reference, it could be concluded that '15-19' and ' 15-17' had the best phenotypic expression and the great potential for largescale cultivation, processing, and utilization. Furthermore, these two germplasms provide novel methodology and references for coconut breeding and variety improvement. The discovery of these high-yield and high-quality coconut germplasm lines is of great significance that cannot be ignored by the coconut industry and processing industry in China.

\section{Conclusion}

This study investigated and analyzed 16 important parameters, including morphological traits and quality characteristics, of 17 coconut germplasm resources in Hainan, thus providing a rich foundation for the preservation, utilization, and research of coconut resources in Hainan and other areas of China. The correlation between multiple traits could be recognized using correlation analyses, PCA, and systematic cluster analyses, thus allowing for a better understanding of several indicators of coconut resources. A variety of trait indicators have been clustered systematically and the evaluation factors for coconut germplasms have been simplified. Two coconut germplasm resources, ' $15-19$ ' and ' $15-17$ ', were screened out through morphological and quality evaluations. They are dwarf coconuts of the sweet water type that cannot only achieve high yield and excellent quality; however, they are suitable for largescale cultivation in Hainan. Therefore, the integration of PCA and cluster analyses is likely to contribute tremendously to improving the ability of the traditional cluster analysis when determining the genetic structure of germplasm collections. This discovery has made a significant contribution to coconut breeding work in China, and it has the potential to enhance the improvement and selection of coconut varieties, promote the progress of the coconut industry, and serve as a powerful reference for future breeding work in China.

\section{Literature Cited}

Antu, M., R. Hasbullah, and U. Ahmad. 2014. Packaging and cold storage Kopyor coconut to maintain quality. J. Keteknikan Pertan. 2(2):1-7.

Campos, C.F., P.E.A. Souza, J.V. Coelho, and M.B.A. Glória. 1996. Chemical composition, enzyme activity and effect of enzyme inactivation on flavor quality of green coconut water. J. Food Process. Preserv. 20(6):487-500, doi: https://doi. org/10.1111/j.1745-4549.1996.tb00761.x.

Cancel, L.E., J.M. Rivera-Ortiz, and E.R.D Hernández. 1976. Storage of frozen coconut pulp and quality of coconut milk extracted. J. Agr. Univ. P. R. 60:99-104.

Cao, C.R., M.X. Zhao, X.Y. Yang, and Z.H. He. 2016. Effect of fertilization with nitrogen, phosphorus and potassium on single fruit weight, edible rate and ash content of jujube. Shaanxi J. Agr. Sci. 62(8):4-7, doi: https://doi. org/10.3969/j.issn.0488-5368.2016.08.002.

Cao, H.X., C.X. Sun, J. Zhang, and R.L. Zhang. 2013. The evaluation and analyzed of fruit quality on Vietnamese coconut resources. Chin J. Trop. Crops 34(12):2419-2423, doi: https:// doi.org/10.3969/j.issn.1000-2561.2013.12.020.

Cao, H.X., C.B. Yan, M.L. Feng, and R.L. Zhang. 2014. The effect of low temperature stress on the changes of nutrient contents in leaves of different coconut varieties. China Trop. Agr. 2:77-79, doi: https://doi.org/10.3969/j.issn.1673-0658.2014. 02.027 .

Chen, H.J., H.S. Li, Q.G. Zhou, and C.T. Wang. 2011. Investigation on coconut germplasm resources in Guangxi and Guangdong. China Trop. Agr. 6:48-50, doi: https://doi.org/10.3969/ j.issn.1673-0658.2011.06.019.

Chen, S.T., Z.L. Ma, W.Q. Tan, H.S. Li, and J. Zhang. 2005. List of palm plants in Hainan coconut grand view garden. Chin. J. Trop. Agr. (4): 38-43, doi: https://doi.org/10.3969/j.issn.10092196.2005.04.011

Deng, F.M., R.J. Zhao, Y.Y. Wang, F. Song, and X.J. Shen. 2018. Study advancement on coconut water preservation and processing technology. Chin. J. Trop. Crops 39(10):2101-2111, doi: https://doi.org/10.3969/j.issn.1000-2561. 2018.10.030

Fan, Y., X.F. Zhao, X.G. Liu, and Y. Yang. 2015. Factor analysis and comprehensive assessment for agronomic traits of peanut. J. Hebei Agr. Sci. 19(6):80-83, doi: https://doi.org/10.16318/ j.cnki.hbnykx.2015.06.022.

Feng, M.L., J. Li, and L.X. Tang. 2015. Correlation analysis between climatic factors and flowering and pollination characteristics of aromatic coconut. Southwest China J. Agr. Sci. 28(4): 
1780-1783, doi: https://doi.org/10.16213/j.cnki. scjas.2015.04.068.

Geethanjali, S., J.A. Rukmani, D. Rajakumar, P. Kadirvel, and P.L. Viswanathan. 2017. Genetic diversity, population structure and association analysis in coconut (Cocos nucifera L.) germplasm using SSR markers. Plant Genet. Resour-C 16(2):156-168, doi: https://doi.org/ $10.1017 /$ S1479262117000119.

Geng, L., F.M. Deng, S.L. Zhao, H. Wang, and M.M. Tang. 2017. Quality changes of mature coconut water under different storage conditions. Chin. J. Trop. Agr. 37(4):70-75, doi: https://doi. org/10.12008/j.issn.1009-2196.2017.04.016.

Hanjaya, C., F.S. Pranata, and Y.R. Swasti. 2020. Quality of virgin coconut oil with addition of peppermint oil. Jurnal Agritech 40(3):215-222.

He, X.Y., S.D. Gao, Y.M. Zhang, L. Tao, L. Tao, X.M. Xiao, and S.B. Ni. 2014. ISSR analysis on genetic diversity of coconut (Cocos nucifera L.) germplasm resources in Yunnan. Chin. Agr. Sci. Bull. 30(1):157-162, doi: https://doi. org/10.11924/j.issn.1000-6850.2013-1964.

Hebbar, K.B., P. Neethu, P.A. Sukumar, M. Sujithra, A. Santhosh, S.V. Ramesh, V. Niral, G.S. Hareesh, P.O. Nameer, and P.V.V. Prasad. 2020. Understanding physiology and impacts of high temperature stress on the progamic phase of coconut (Cocos nucifera L.). Plants 9(12):1651, doi: https://doi.org/10.3390/PLANTS9121651.

Kabir, F.N.A., M.S.R. Palleb, U.H. Mimi, M.M. Hosain, and T. Sharmin. 2020. Quality evaluation and storage study of coconut bar. Acta Scientifica Malaysia 4(1):19-26, doi: https:// doi.org/10.26480/asm.01.2020.19.26.

Ke, Y.P. and J.C. Guo. 1994. Current Situation and countermeasures of development and utilization of coconut resources in Hainan. Chin. J. Trop. Agr. 3:15-18.

Khathir, R., S. Hartuti, and N. Fadillah. 2021. The quality assessment on fermented virgin coconut oil treated under microwave heating. IOP Conf. Ser. Earth Environ. Sci. 644(1):012046, doi: https://doi.org/10.1088/1755-1315/644/1/012046.

Kong, D.W., D.Q. Chen, L.Q. Zhou, Y.P. Wang, and S.G. Li. 2005. The principle components analysis of several agronomic and yield traits of rice. Chin. Agr. Sci. Bull. 21(8):117-119, doi: https:// doi.org/10.3969/j.issn.1000-6850.2005.08.034.

Lédo, A.S., E.E.M. Passos, H.R. Fontes, J.M.S. Ferreira, V. Talamini, and W.A. Vendrame. 2019. Advances in Coconut palm propagation. Rev. Bras. Frutic. 41(2):E-159, doi: https://doi. org/10.1590/0100-29452019159.

Lei, W.P., H. Zhou, K. Wu, X.R. Zhou, S.B. You, and C.G. Liu. 2020. Optimization of technological conditions and characteristic flavor composition analysis of fermented coconut pudding. Stor. Proc. 20(5):135-142, doi: https://doi.org/ 10.3969/j.issn.1009-6221.2020.05.022.

Li, H. S., C. X. Sun, H. X. Cao, H. Q. Zhou, and H. K. Fan. 2009. Preliminary studies on morphological characteristics and adaptability of different coconut varieties. Acta Agr. Jiangxi 21(11):46-47, 50, doi: https://doi.org/10.3969/j. issn.1001-8581.2009.11.016.

Li, Y.L. and A.M. Zhang. 2012. Analysis on the dialectical relationship between plant vegetative growth and reproductive growth. Chin. Hort. Abs. 28(2):36-37, doi: https://doi.org/10.3969/ j.issn.1672-0873.2012.02.017.

Lima, E.B.C., C.N.S. Sousa, L.N. Meneses, N.C. Ximenes, J.M.A. Santos, G.S. Vasconcelos, N.B.C. Lima, M.C.A. Patrocínio, D. Macedo, and S.M.M. Vasconcelos. 2015. Cocos nucifera (L.) (Arecaceae): A phytochemical and pharmacological review. Braz. J. Med. Biol. Res.
48(11):953-964, doi: https://doi.org/10.1590/ 1414-431X20154773.

Liu, R.J., X. Guo, M. Cheng, L.Y. Zheng, M.Y. Gong, M. Chang, Q.Z. Jin, and X.G. Wang. 2019. Effects of chemical refinement on the quality of coconut oil. J. Food Sci. Technol. 56(6):3109-3116, doi: https://doi.org/10.1007/ s13197-019-03810-w.

Liu, Z.X., X.Z. Cheng, G.M. Zhou, and K.H. Hou. 2011. An entropy-based evaluation model for multiple objective decision making on adzuki bean germplasm. J. Plant Genet. Resour. 12(1):54-58, doi: https://doi.org/10.13430/j. cnki.jpgr.2011.01.012.

Maji, A.T. and A.A. Shaibu. 2012. Application of principal component analysis for rice germplasm characterization and evaluation. J. Plant Breed. Crop Sci. 4(6):87-93.

Mao, Y. and G.H. Fu. 2011. Research on coconut germplasm resource in Hainan province. J. Anhui Agr. Sci. 39(01):439-442, doi: https:// doi.org/10.3969/j.issn.0517-6611.2011.01.170.

Mao, Z.S. and W.M. Qiu. 2006. Coconut germplasm resources. China Agriculture Press, Beijing.

Santos, M.M.S., C.F. Lacerda, A.L.R. Neves, C.H.C. Sousa, A.R. Ribeiro, M.A. Bezerra, I.C.S. Araújo, and H.R. Gheyi. 2020. Ecophysiology of the tall coconut growing under different coastal areas of northeastern Brazil. Agr. Water Manage. 232:106047, doi: https://doi. org/10.1016/j.agwat.2020.106047.

Meerow, A.W., R.J. Wisser, S.J. Brown, D.N. Kuhn, R.J. Schnell, and T.K. Broschat. 2003. Analysis of genetic diversity and population structure within Florida coconut (Cocos nucifera L.) germplasm using microsatellite DNA, with special emphasis on the Fiji Dwarf cultivar. Theor. Appl. Genet. 106(4):715-726, doi: https://doi.org/10.1007/s00122-002-1121-z.

Mepba, H.D. and S.C. Achinewhu. 2003. Effects of processing on protein nutritive quality of coconut Cocos nucifera products. Plant Foods Hum. Nutr. 58(1):15-25, doi: https://doi.org/ 10.1023/A:1024006620501.

Mulyadi, A.F., M. Schreiner, and I.A. Dewi. 2019. An overview of factors that affected in quality of virgin coconut oil. AIP Conf. Proc. 2120:050007.

National Health and Family Planning Commission of P.R. China. 2016. GB 5009.229-2016. National Food Safety Standard: Determination of Acid Value in Food. Standards Press of China, Beijing.

National Health and Family Planning Commission of P.R. China, National Foods and Medical Products Administration. 2016a. GB 5009.52016. National Food Safety Standard: Determination of Protein in Food. Standards Press of China, Beijing.

National Health and Family Planning Commission of P.R. China, National Foods and Medical Products Administration. 2016b. GB 5009.62016. National Food Safety Standard: Determination of Fat in Food. Standards Press of China, Beijing.

Pandey, S. and S. Gupta. 2020. Diversity analysis of ACC deaminase producing bacteria associated with rhizosphere of coconut tree (Cocos nucifera L.) grown in Lakshadweep islands of India and their ability to promote plant growth under saline conditions. J. Biotechnol. 324:183-197, doi: https://doi.org/10.1016/j.jbiotec.2020.10.024.

Parlindungan, J.Y., J.Y. Parlindungan, H. Hitijahubessy, J.J. Pongkendek, N.B. Sumanik, and A.L. Rettob. 2020. Increasing the quality of virgin coconut oil (VCO) using activated carbon adsorbent from candlenut shell (Aleurites mollucana). J. Phys. Conf. Ser. 1569(4):042049, doi: https://doi. org/10.1088/1742-6596/1569/4/042049.
Preethi, P., S. Rahman, S. Naganeeswaran, A.A. Sabana, K.P. Gangaraj, B.A. Jerard, V. Niral, and M.K. Rajesh. 2020. Development of ESTSSR markers for genetic diversity analysis in coconut (Cocos nucifera L.). Mol. Biol. Rep. 47(12):9385-9397, doi: https://doi.org/10.1007/ s11033-020-05981-8.

Raghubeer, E.V., B.N. Phan, E. Onuoha, S. Diggins, V. Aguilar, S. Swanson, and A. Lee. 2020. The use of high-pressure processing (HPP) to improve the safety and quality of raw coconut (Cocos nucifera L) water. Intl. J. Food Microbiol. 331:108697, doi: https://doi.org/ 10.1016/j.ijfoodmicro.2020.108697.

Riangwong, K., S. Wanchana, W. Aesomnuk, C. Saensuk, P. Nubankoh, V. Ruanjaichon, T. Kraithong, T. Toojinda, A. Vanavichit, and S. Arikit. 2020. Mining and validation of novel genotyping-by-sequencing (GBS)-based simple sequence repeats (SSRs) and their application for the estimation of the genetic diversity and population structure of coconuts (Cocos nucifera L.) in Thailand. Hort. Res. 7(1):1-11, doi: https://doi.org/10.1038/s41438-020-00374-1.

Saraçli, S., N. Doğan, and İ. Doğan. 2013. Comparison of hierarchical cluster analysis methods by cophenetic correlation. J. Inequal. Appl. 1:1-8, doi: https://doi.org/10.1186/1029-242X-2013-203.

Sarkar, A., T. Ahmed, M. Alam, S. Rahman, and S.K. Pramanik. 2020. Influences of osmotic dehydration on drying behavior and product quality of coconut (Cocos nucifera). Asian Food Sci. J. 15(3):21-30, doi: https://doi.org/10.9734/ afsj/2020/v15i330153.

Schober, P., C. Boer, and L.A. Schwarte. 2018. Correlation coefficients: Appropriate use and interpretation. Anesth. Analg. 126(5):1763-1768, doi: https://doi.org/10.1213/ANE.0000000000002864.

Sun, C.X., J. Zhang, H.K. Fan, and D.Q. Lin. 2014. Test and assessment of critical morphological and quality factors of coconut resources. Chin. J. Trop. Crops 35(12):2355-2361, doi: https://doi. org/10.3969/j.issn.1000-2561.2014.12.007.

Sun, C.X., J. Zhang, H.T. Qin, H.K. Fan, H.X. Cao, and S.L. Zhao. 2012. Ecological adaptation of Vietnamese coconut resources in Hainan. Chin. J. Trop. Crops 33(10):1903-1909, doi: https:// doi.org/10.3969/j.issn.1000-2561.2012.10.035.

Suzana, M., Y. Zulkifli, M. Marhalil, N. Rajanaidu, and O.A. Meilina. 2020. Principal component and cluster analyses on Tanzania oil palm Elaeis guineensis JACQ. germplasm. J. Oil Palm Res. 32(1):24-33.

The Ministry of Agriculture of P.R. China. 2009. NY/T 1810-2009. Descriptors standard for germplasm resources of coconut (Cocos nucifera L.). Standards Press of China, Beijing.

The Ministry of Agriculture of P.R. China. 2013. NY/T 2516-2013. Guidelines for the conduct of tests for distinctness, uniformity and stability of coconut (Cocos nucifera L.). Standards Press of China, Beijing.

The Ministry of Agriculture of P.R. China. 2014. NY/T 2637-2014. Refractometric method for determination of total soluble solids in fruits and vegetables. Standards Press of China, Beijing.

The Ministry of Agriculture of P.R. China. 2015. NY/T 2742-2015. Determination of soluble sugar in fruits and derived products: 3,5-dinitrosalicylic acid colorimetry. Standards Press of China, Beijing.

Udaya, P.N.K., B.E. Jasmine, R. Vidhya, N.S. Sripriya, and S. Bhuvaneswari. 2020. Phytochemical composition and antioxidant activity of coconut cotyledon. Heliyon 6(2):E03411, doi: https://doi.org/10.1016/j.heliyon.2020.e03411.

Wang, H., W.J. Chen, X.F. Long, S.L. Zhao, and Q.Y. Xia. 2013. Studies on activity distribution of LPS, 
PPO and POD in different parts of coconut. Guangdong Agr. Sci. 40(16):101-103, doi: https:// doi.org/10.3969/j.issn.1004-874X.2013.16.033.

Wang, L.Y., X.J. Liu, D.P. Xu, C.S. Chen, G.S. Nie, and B. Xiang. 2019. Advances in regulation techniques for vegetative and reproductive growth of trees species. World For. Res. 32(6):6-12, doi: https://doi.org/10.13348/j.cnki. sjlyyj.2019.0085.y.

Wang, Y. Y., Q. Y. Xia, R. Li, F. M. Deng, X. J. Shen, and H. Wang. 2020. Effects of different freezing storage temperatures on the preservation and processing characteristics of coconut meat. The Food Ind. 41(5):5-8, doi: https://doi. org/CNKI:SUN:SPGY.0.2020-05-002.

Wijayati, W., T. Rahayuningsih, and D. Puspitasari. 2019. The effect of ginger variety and incubation time on the quality of coconut oil (Cocos Nucifera). SSRN Elec. J., doi: https:// doi.org/10.2139/ssrn.3486997.
Xia, Q.Y., R. Li, S.L. Zhao, M.Y. Zhang, and X.J. Li. 2007. The utilization value and comprehensive processing technology of coconut. China Trop. Agr. 3:37-38, doi: https://doi.org/ 10.3969/j.issn.1673-0658.2007.03.019.

Yang, Y.D., M.A. Saand, W.B. Abdelaal, J. Zhang, Y. Wu, J. Li, H.K. Fan, and F.Y. Wang. 2020. iTRAQ-based comparative proteomic analysis of two coconut varieties reveals aromatic coconut cold-sensitive in response to low temperature. J. Proteomics 220:103766, doi: https://doi.org/10.1016/j. jprot.2020.103766.

Zhang, C. 2011. Comprehensive review of the nutritious value and application of coconuts. $\mathrm{J}$. Sichuan Tour. Univ. 1:26-28, doi: https://doi. org/10.3969/j.issn.1008-5432.2011.01.008.

Zhang, Q., Z.W. Wei, T.F. Yan, and X.L. Geng. 2021. Identification and evaluation of genetic diversity of agronomic traits in oat germplasm resources. Acta Agrestia Sinica 29(2):309-316, doi: https://doi.org/10.11733/j.issn.1007-0435. 2021.02.012.

Zhang, R.N., B. Zhou, and S.T. Xu. 2020. Discussion and consideration of plant landscape design in college campus under the background of beautiful campus: Taking Haidian campus of Hainan University as an example. Tianjin Agr. Sci. 26(6):85-90, doi: https://doi.org/ 10.3969/j.issn.1006-6500.2020.06.020.

Zhao, X. 2019. Landscape investigation and suggestions for optimization on the current situation of campus street tree in tropical areas: Taking Hainan University as an example. Xiandai Hort. 7:33-35, doi: https://doi.org/10.3969/ j.issn.1006-4958.2019.07.015.

Zhou, L.X. and H.X. Cao. 2018. SSR analysis on genetic diversity in coconut germplasm resource. J. Southern Agr. 49(9):1683-1690, doi: https:// doi.org/10.3969/j.issn.2095-1191.2018.09.01. 